\title{
CityLabs: Making Cities, Making Futures
}

\author{
Steven Van Wolputte, Ann Cassiman and Filip De Boeck
}

This chapter is part of an ongoing research project ('CityLabs') focusing on the role that so-called makerspaces and hackerspaces (may) play in developing new forms of bottom-up urbanity. While too soon to lay out the project's findings (ethnographic fieldwork is ongoing in Accra, Cape Town, Lomé and Nairobi), the intention here is to present the project's vantage point and ambitions.

While the scholarly literature has long emphasized the resilience and creativity of urbanites around the world, public discourse on African cities is still dominated by dystopian views of lack (of money, infrastructure, interest) and precariousness, usually introduced or followed by a dire warning that within a few decades half the continent's population will be living in an urban environment. Similar fears about the urban poor were raised in nineteenth-century Europe. It took two world wars and a global pandemic (not the current one) before effective change was about to crystallize.

It is against this background that the project's starting question was how actors in the broad field of the creative economies across the African continent (not only engineers, architects and urban planners, but also hackers, artists and tinkerers) imagine and redefine the city of the future. Along with Harvey (2000), we indeed see these makerspaces and hackerspaces as 'spaces of hope' where local solutions to local challenges are being forged. These solutions are not imported, but generated on the spot, as part of a process that could be viewed as an urbanization from below.

The CityLabs project started in 2018 with funding from the Catholic University of Leuven. It is the third component of a research triptych on African cities initiated and carried out by members of the same university's Institute of Anthropological Research in Africa. A first project (on secondary cities, 200712) started from the observation that most research on African urbanity has concentrated on the continent's megacities, often taken as a pars pro toto for the 
nation. ${ }^{1}$ Though obviously not without its merits, this rather one-sided focus diverts attention away from how these urban centres relate to wider national (or international) and peripheral, semi-urban and rural contexts. Moreover, this focus on major urban centres frequently disregards the much smaller secondary cities 'off the map' (Robinson 2002), even if they often 'work' better than the metropole where life is fraught and shaped by much stronger social and economic tensions and contradictions, and even if most people live not in the metropolis but in these secondary, smaller cities (De Boeck et al. 2010; Ruszczyk et al. 2020).

A subsequent project (on planning poverty, 2013-17) honed in on the many satellite cities mushrooming throughout the continent, on the increasing inequality that planning interventions engender and on the growing gap between urban planning and the daily, lived experience they exemplify. In many cases, the gap is widened not only by the total absence of any participatory urban planning strategies, but also by the increasing role of new forms of volatile venture capital. To varying degrees, governance institutions across Africa are increasingly dominated by the forces of globalization and by the private sector being able to transcend the powers of local, provincial and national states. These dynamics are particularly concentrated in urban areas (De Boeck and Plissart 2004; Lund 2007; Trefon 2004). As a result, in many cities throughout Africa (whether Kinshasa, Accra, Dakar, Kigali, Luanda, Nairobi or Khartoum) official urban reform plans seem to generate rather than overcome new geographies of inclusion and exclusion. There is a constant tension between the reality lived by millions of urban dwellers, and the official vision of the urban future that political leaders and urban planners seem to share.

When we started preparing for the CityLabs project, we realized that we had perhaps paid too little attention to the resilience and creativity of urbanites, and that we had gone along too far with what Gyan Prakash (2010) poignantly labelled 'noir urbanisms'. Indeed, the literature on African urbanscapes is replete with analyses that stress the dysfunctional character of urban spaces across the African continent. In the field of urban anthropology, this tendency to read the African city as a pathological space of 'enduring failures - to the exclusion of almost everything else' (Myers and Murray 2006: 2), was perhaps further enhanced by the turn in anthropological theory since the 1980s towards what Ortner (2016) called 'dark anthropology', namely an anthropology that focuses on the harsh dimensions of social life (power, domination,

1 The term secondary cities is, at first sight, confusing: a smaller city such as Kikwit (80o,ooo inhabitants by now) is small in comparison with Kinshasa with an estimated 12 million city dwellers, but still quite large in comparison with most European cities. 
inequality, and oppression), and on the subjective experiences of these dimensions in the form of depression, uncertainty, and hopelessness. Insightful as such a focus on the perils of urban lived experiences might be, it also runs the risk of portraying urban residents as the passive victims of processes beyond their control.

\section{$3 \quad$ Making Cities, Making Futures}

From its onset, CityLabs has sought to highlight how the inhabitants of Africa's urban worlds claim or reclaim their cities, become active urban agents, invent new forms of cohabitation and collective action, and design alternative futures for the urban contexts in which they live. The aim is to tap the existing potential to fabricate new urban futures, to turn what Simone (2016) called 'uninhabitable' into a possibility beyond either the tired, broken dreams of 'modern' urban life propagated by former colonial urban planning ideals, or the latest images and spectres of the new neoliberal city that circulate widely across Africa (see De Boeck 2011, 2019; Watson 2014; for an exploration of futuring, see this volume's introduction). For most urbanites, however, these models remain in a distant utopian future towards which no real or feasible roadmap seems to exist.

During the design phase, it was decided to concentrate on four cities (Lomé, Accra, Cape Town, and Nairobi), and to understand the impact of these hubs on the urban landscape along three axes - (a) knowledge (how to reconcile hi-tech innovations with local skills and worldviews); (b) environment (how the actors envision sustainable urban development); and (c) products (what technological, cultural or aesthetic void do they intend to fill?) Thus, by thinking and working with 'makers', by analysing utopian or dystopian ideas of what the future may hold, and by scrutinizing the kinds of solutions or alternatives actors may offer, CityLabs plans to introduce an anthropology of what is possible (Kleist and Jansen 2016; Sliwinski 2016; Zigon 2009).

\section{$4 \quad$ Making the City}

A first source of inspiration came from De Boeck and Baloji's (2015) research in Kinshasa where, during their fieldwork, they stumbled on the 'Tower', a 12-storey building soaring high above a desultory landscape of warehouses, industrial plants, railroad tracks and new houses under construction. In defiance of gravitational laws and urban zoning rules, this unusual architectural 
statement is one of the city's strangest and most enigmatic landmarks - a giant question mark begging us to reflect on the nature of the city, the heritage of its colonial modernist architecture, the awfulness of its current infrastructure, and its continuing capacity to generate utopian urban dreams. In the words of the middle-aged medical doctor who started to construct this ragged skyscraper without a plan or the professional help of architects, the tower is an attempt to transcend bare life and the mere level of survival that the city of Kinshasa imposes on its inhabitants, and to propose an alternative vision of a better urban world.

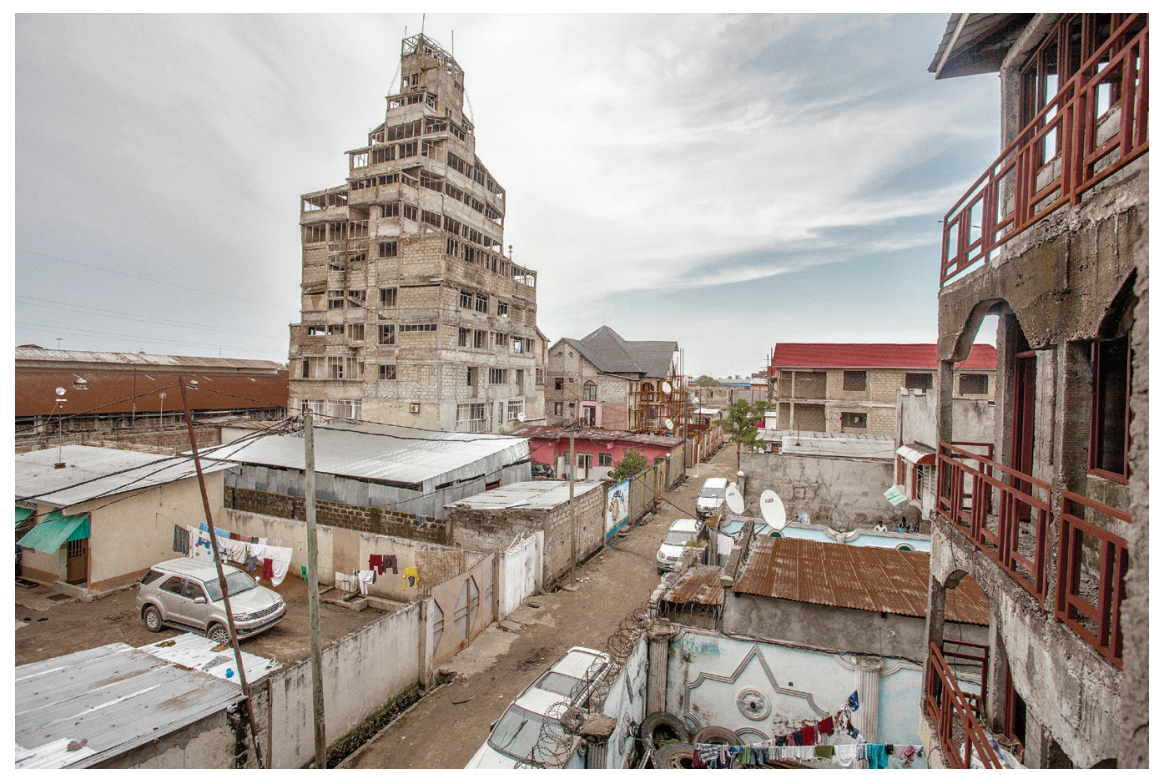

FIGURE 1 The tower, 7 th street, municipality of Limete, Kinshasa, 2015 SAMMY BALOJI

A second inspiration was AbdouMaliq Simone's (2004a) description of $L a$ Nouvelle Liberté (the new liberty), a statue that in Douala, Cameroon, transformed an anonymous but crucial roundabout into a thriving meeting point and bustling hub. Made of scrap material by Joseph Francis Sumégné, the construction and placement of the statue was financed by a crowdfunding campaign organized by the NGO Doual'Art. Its main outcome, says Simone, was that it got people thinking and talking about what kind of city they wanted. Moreover, to the extent that La Nouvelle Liberté became a public landmark it also forced the municipal authorities to improve the surrounding infrastructures and the roads leading to the roundabout. Also, as Dominique Malaquais (2006) convincingly demonstrates, the statue instigated lively political debates on identity and self-determination, and inspired other artists to work along 
similar principles. As Malaquais (2011: 8) argued elsewhere, these steAmrelated activities have a real impact on the cityscape. What they have in common is that they exemplify alternative, grassroots ways of shaping city space. They offer alternative locations to reflect on, think about and do something with the challenges contemporary urbanites are facing. The city they have in mind differs radically from the official urban propositions envisaged by politicians, urban planners or real estate investors.

Around that time, in 2017, the so-called maker movement made a few headlines in the national and international press and, although none of the inspirations above had any formal association with the maker movement, La Nouvelle Liberté was inaugurated in 1996, both projects were run along very similar principles. In Lomé, Togo, WoeLab and its founder Sénamé Koffi Agbodjinou acquired instant fame in 2016 by assembling a $3 \mathrm{D}$ printer from discarded printer parts (even if his more encompassing vision on architecture and the city received far less attention). This news item reflected the words of Emeka Okafor (founder of Maker Faire Africa) when he observed that, 'Making is central to leading Africa where it needs to be: a developing, problem solving region. ... It's imperative that communities from Cairo to the Cape unfetter their populations with tools from within' (King et al. 2014).

In more than one sense, Okafor's words heralded the coming of age of studies on science and technology in Africa. Until recently, these studies concentrated mainly on the creative use of 'imported' technology (for an incisive critique of this presumed 'lack' of innovation in Africa, see Gewald et al. 2012; Hart 2016; Pype 2017). However, creative minds throughout the continent are increasingly developing their own technologies to cope with local demands, making Africa the world leader in, for instance, mobile banking. As Clapperton Mavhunga (2017: 19) notes, 'Credit often unfairly goes to the gadget, as in see how mobile technology is changing Africa. Wrong! We should instead see how Africans are changing mobile technology' (italics in original).

What most approaches to innovation and technology in Africa have in common is that they are usually firmly located in the city, but they say little about the city, or about the interrelationship between the city and technology. Much recent urban research has illustrated how newly built infrastructures (including the infrastructural platforms of so-called 'smart cities'), invariably implemented top-down, have exacerbated existing inequalities and created new 'urbanisms of exception' (Murray 2017; see also De Boeck 2011; Parnell and Pieterse 2014; Watson 2014). Conversely, scholars who take urbanity as their focus have started to concentrate extensively on the importance of (often crumbling or failing) material and social infrastructures in shaping life in the African city (cf. Larkin 2013; Simone 2004b). Recent scholarship has given us 
detailed examples of how local actors craft new destinations for abandoned landmark buildings, or find new uses for existing but deficient hydraulic and electrical infrastructures (Anand 2017; De Boeck and Baloji 2016; Hoffman 2017), or creatively recycle locally available scrap and waste materials.

\section{Decentring the Global Maker Movement}

By 2017, the global maker movement had gained some visibility after its formal baptism the decade before. It quickly spread its wings and, at present, more than 2000 makerspaces are recognized throughout the world, a large and growing number of them in the Global South. Though extremely heterogeneous, the maker movement inspires people to 'do something', gather around a common project and build a sense of common purpose, accrue social capital through online and offline networks, and wrench control over their lives from the hands of experts and elites (Davies 2017: 19-27). As such, it is often heralded as a new industrial revolution, or new culture of (global) citizenship (Anderson 2012) that is part of, and speaks to, a broader social movement that addresses some of the social anxieties (such as food and job security) that, in Europe and the USA, gained salience after the 2008 financial crisis (Davies 2017).

Yet, there is considerable tension between the movement's rhetoric and practice, and the way 'making' is being commercialized and propagated in Europe and the USA has attracted quite a lot of criticism. This includes the observation that, despite its staggering heterogeneity, mainstream maker culture caters mainly for a highly educated, predominantly male, white middle-class that strongly identifies with the STEM disciplines, a bias that is also apparent in what they are making and in a strong emphasis on individual brilliance and achievement. Bearing this criticism in mind, one can indeed expect local makerspaces elsewhere, while subscribing to the same ideals, to lay different emphases. Over the past five years, for instance, some 200 (and counting) recognized makerspaces have popped up in various parts of the African continent, voicing a "commitment to origin, ingenuity and innovation ... [to redefine] the future of the world's most promising continent through our own authentic, relentless African ingenuity" (MFA 2021). Like their American, Asian, or European counterparts they are characterized by a particular attitude towards knowledge (emphasizing open and communal access), an overall anti-authoritarian ethos, and a deeply rooted concern for the environment and issues concerning sustainability. As they engineer their "inventions for the 
everyday" (Mavhunga 2014) - homemade answers to local problems rather than imported and often ill-adapted foreign-made technological solutions these creative economies reconcile hi-tech with local ingenuity, worldviews and modes of learning.

Though the maker movement was an initial source of inspiration for the CityLabs project, the makerspaces and hackerspaces (and we quickly learned to use these terms in a very broad sense) with which the team ended up did not necessarily have links with the mainstream maker movement. In fact, it would be wrong to see the various initiatives (from seamstresses and cell phone hackers in Accra, Ghana, to coding lessons in Lomé, software developers in Nairobi, or city furniture makers in Cape Town) as mere outlets of a Euro-American 'maker culture'. The rationale behind CityLabs, however, is not to look at how 'Africa' is 'adopting' maker culture (in the words of one blogger "as though Westerners had invented 'making' and Africa were a homogeneous spot") (Yoder 2015; see also Nkoudou 2017). If anything, the relative success of maker culture on the continent has more to do with the affinity between 'making' and locally existing ways of knowing and learning and with the social, economic and political dynamics of its cities, such as the presence of a large cohort of young, highly educated and skilled but jobless professionals (Cooper and Morell 2014; Mavhunga 2017).

Though it is too soon to arrive at conclusions, tentative results suggest that it might be a good idea to operationalize the three axes identified at the beginning of the project into five arenas. The first such arena would be knowledge. How is technical knowledge being reconciled with other ways of knowing? What does an Africa-centred knowledge look like, and how is learning organized? How open is open access in the context of the Global South, given that access is often blocked or at least impeded by structural inequalities and power imbalances? Given that makerspaces tend to be highly gendered, and to be dominated by male professionals, what impact do they have on gender relations, or on intergenerational tensions? How does one stop more powerful markets hijacking this open access (as happened, for instance, with traditional medicine)? What about patents and property rights?

A second arena is art. Makerspaces and hackerspaces obfuscate the boundary between artist and engineer, between craftsperson and designer, or between professional and amateur. All these scenes function more or less according to 
the principles set out by the maker movement. From the tools they invent to the devices they engineer, the codes they hack, or the statues they erect, what is it that makerspaces and hackerspaces produce? And how do they do it?

Third, this emphasis on produce and materials implies an ethnographic focus on the processes involved in their production and on how these skills and techniques, and indeed the technology itself, change as they travel through these makerspaces. At the same time, however, it is also important to realize that technology is not gender-neutral: in small-scale gold mining sites in Tanzania, the introduction of new technologies (such as metal detectors) only widened the gap between male and female miners (Verbrugge and Van Wolputte 2015). Hence the project also looks at the social life of techniques, and how local knowledge is welded together with more innovative and grassroots ways of doing things.

A fourth arena concerns how these makerspaces relate to the particular urban ecology of which they are a part, and on how makers and hackers imagine their future and that of their neighbourhood and city. Indeed, across the African cityscape urban inhabitants develop their own specific forms of urbanism and infuse the city with their own praxis, values, moralities and temporal dynamics. The small-scale modes of action and creation that punctuate urban and peri-urban living still provide residents with an urban politics of the possible. These - often unsteady, provisional and constantly shifting - possibilities and action schemes are perhaps not the only ones available to urban dwellers; it is, however, impossible to underestimate their importance as a lever for collective action. One aspect of this maker ecosystem, then, certainly is the sustainability of urban development. In the hubs under consideration recycling may be one of the preferred 'methods' of the maker movement, and waste a preferred resource, this often is not a matter of choice but of necessity.

Fifth and finally, urban residents - as local producers and controllers of infrastructure and technology, rather than as local consumers of imported technology - are highly skilled at discovering itineraries beyond the obvious, and at exploiting more invisible paths and possibilities that lie hidden in the folds of urban domains and experiences. These city dwellers have successfully trained themselves to tap into this imbroglio, and to exploit to the full the possibilities it offers. Of what then consists such entrepreneurship? How do makers finance their projects, and are alternative routes (such as pyramid saving schemes) sustainable in the long run? To what extent are the alternatives they propose (the sharing economy, crowdfunding, see the example of La Nouvelle Liberte above) viable, when the alternative is all there is or, at best, is unpredictable and unreliable. 


\section{Concluding Thoughts}

Makerspaces and hackerspaces - in the broadest possible sense - are indeed urban phenomena. First of all, in their contemporary form, they require access to (social and virtual) networks and infrastructure - including people as infrastructure (Simone 2004b). Second, as people regain control of the means of production - be it as a lifestyle or as an ideological choice, out of necessity or for artistic reasons - 'making is returning to cities in new and surprising ways' (Hirschberg et al. 2016: 24). Third, this also implies that makers, living in the city, are increasingly involved with the city, trying to rework and improve it, or at least prevent it from worsening, in their own, idiosyncratic ways and according to their own utopian ideals or dystopian fears (Pieterse 2008; Ringel 2016). This also implies that makerspaces or hackerspaces are invariably oriented towards the future and the future of their urban environment, especially when taking into account their shared ideals of open access, open source, and sustainability.

This project thus also proposes looking at city futures through the window of makerspaces as examples of creative hubs where, often quite literally, the future is made; where attempts are engineered to bridge the growing gap between the haves and have-nots, or between those with access to global mobility and those 'stuck in the compound'; where the different reference frames, registers, repertoires and velocities of the city are negotiated; and where a more just, equitable and sustainable future - again, quite literally - is being assembled or hacked.

\section{References}

Anand, N. 2017. Hydraulic city: Water and the infrastructures of citizenship in Mumbai. Durham, NC: Duke University Press.

Anderson, C. 2012. Makers: The new industrial revolution, New York: Crown Publishing Group.

Cooper, B. and R. Morrell (Eds). 2014. Africa-centred knowledges: Crossing fields and worlds. Melton, Woodbridge: James Currey.

Davies, S. R. 2017. Hackerspaces: Making the maker movement. Cambridge, UK: Polity Press.

De Boeck, F. 2011. "Inhabiting ocular ground: Kinshasa's future in the light of Congo's spectral urban politics." Cultural Anthropology, 26, 2: 263-286.

De Boeck, F. 2019. "Future city: Congo's urban worlds in the age of the global city/La ville du future: Univers urbains du Congo à l'ère de la ville mondiale." In Kinshasa 
chronicles/Kinshasa chroniques, edited by D. Malaquais, 300-307. Montreuil: Les Éditions de l'OEil.

De Boeck F. and S. Baloji. 2015. "The tower. A concrete utopia. Notes on a videoinstallation by Sammy Baloji and Filip De Boeck." In Africa. Architecture Culture Identity, edited by M. Holm, J. Kallehauge and M. M. Kallehauge, 84-88. Copenhagen: Louisiana Museum of Modern Art.

De Boeck, F. and S. Baloji. 2016. Suturing the city: Living Together in Congo's urban worlds. London: Autograph.

De Boeck, F. and M.-F. Plissart. 2004. Kinshasa. Tales of the invisible city. Gent: Ludion.

De Boeck, F., A. Cassiman and S. Van Wolputte. 2010. "Recentering the city: An anthropology of secondary cities in Africa." In Proceedings of African Perspectives 20og. The African inner city:[Re] sourced, edited by K A. Bakker, 33-42. Pretoria: Department of Architecture, University of Pretoria.

Gewald, J.-B., A. Leliveld and I. Peša. 2012. Transforming innovations in Africa: Explorative studies on appropriation in African societies. Leiden: Brill.

Hart, J. 2016. Ghana on the go: African mobility in the age of motor transportation. Bloomington: Indiana University Press.

Hirschberg, P., D. Dougherty and M. Kadanoff. 2017. Maker city book. Santa Rosa, CA: Make Community. https://makercitybook.com [17/12/2017].

Hoffman, D. 2017. Monrovia modern: Urban form and political imagination in Liberia. Durham, NC: Duke University Press.

King, E., S. Santoso and K. Gage. 2014. Making for a stronger Africa. White House blog, 19 August. https://obamawhitehouse.archives.gov/blog/2014/o8/19/makingstronger-africa.

Kleist, N. and S Jansen. 2016. "Introduction: Hope over time - crisis, immobility and future-making." History and Anthropology, 27, 4: 373-392.

Larkin, B. 2013. "The politics and poetics of infrastructure." Annual review of Anthropology, 42, 1: 327-343.

Lund, C. 2007. Twilight institutions: Public authority and local politics in Africa. Oxford: Blackwell.

Malaquais, D. 2006. "Une nouvelle liberté? Art et politique urbaine à Douala (Cameroun)." Afrique \& histoire, 5, 1: 111-134.

Malaquais, D. 2011. "Anti-teleology." In African cities reader II: Mobilities and fixtures, edited by N. Edjabe and E. Pieterse, 7-23. Vlaeberg: Chimurenga/African Centre for Cities.

Mavhunga, C. C. 2014. Transient workspaces. Technologies of everyday innovation in Zimbabwe. Cambridge, MA: Mit Press.

Mavhunga, C. C. (Ed.). 2017. What do science, technology and innovation mean from Africa? Cambridge, MA: MIT Press. 
MFA (Maker Faire Africa) 2021. "About MFA" website. http://makerfaireafrica.com/ about/.

Murray, M J. 2017. The urbanism of exception: The dynamics of global city building in the twenty-first century. Cambridge: Cambridge University Press.

Myers, G. A. and M. J. Murray. 2006. "Introduction: Situating contemporary cities in Africa." In Cities in contemporary Africa, edited by M. J. Murray and G. A. Myers, 1-30. New York: Palgrave Macmillan.

Nkoudou, T. H. M. 2017. "Benefits and the hidden face of the maker movement: Thoughts on its appropriation in African context." Liinc en Revista, 13, 1: 72-88.

Ortner, S. B. 2016. "Dark anthropology and its Others." HAU: Journal of Ethnographic Theory, 6 1: 47-73.

Parnell, S. and E. Pieterse. 2014. Africa's urban revolution. London: Zed Books.

Pieterse, E. 2008. City futures. Confronting the crisis of urban development. London/ Cape Town: Zed Books/uct Press.

Prakash, G. 2010. Noir urbanisms: Dystopic images of the modern city. Princeton, NJ: Princeton University Press.

Pype, K. 2017. "Smartness from below: Variations on technology and creativity in contemporary Kinshasa." In What do science, technology, and innovation mean from Africa?, edited by C. C. Mavhunga, 97-115. Cambridge, MA: wT Press.

Ringel, F. 2016. "Beyond temporality: Notes on the anthropology of time from a shrinking fieldsite." Anthropological Theory, 16, 4: 390-412.

Robinson, J. 2002. "Global and world cities: A view from off the map." International Journal of Urban and Regional Research, 26, 3: 531-554.

Ruszczyk, H. A., E. Nugraha and I. de Villiers. 2020. Overlooked cities: Power, politics and knowledge beyond the urban South. Abingdon: Taylor \& Francis.

Simone, A. 2004a. For the city yet to come: Changing African life in four cities. Durham: Duke University Press.

Simone, A. 2004b. "People as infrastructure: Intersecting fragments in Johannesburg." Public Culture, 16, 3: 407-429.

Simone, A. 2016. "The uninhabitable? In between collapsed yet still rigid distinctions." Cultural Politics, 12, 2: 135-154.

Sliwinski, A. 2016. "The value of promising spaces: Hope and everyday utopia in a Salvadoran town." History and Anthropology, 27, 4: 430-446.

Trefon, T. 2004. Reinventing order in the Congo. London: Zed Books.

Verbrugge, H. and S. Van Wolputte. 2015. "Just picking up stones: Gender and technology in a small-scale gold mining site." In The Routledge handbook of gender and development, edited by A. Coles, L. Gray and J. Momsen, 173-184. New York: Routledge.

Watson, V. 2014. "African urban fantasies: Dreams or nightmares." Environment and Urbanization, 26, 1: 215-231. 
Yoder, B. 2015. "Let's talk about the maker movement in Africa." Parisoma.com blog, 4 July. https://medium.com/parisoma-blog/let-s-talk-about-the-maker-movementin-africa-a634005oc55b.

Zigon, J. 2009. "Hope dies last: Two aspects of hope in contemporary Moscow." Anthropological Theory, 9, 3: 253-271. 